\title{
A note on the effect of supplementation of rye diets with arabinoxylan degrading enzymes on production parameters of broiler chickens ${ }^{*}$
}

\author{
D. Boros and B. Rek-Ciepła \\ Laboratory of Nutritional Evaluation of Plant Materials, \\ Institute of Plant Breeding and Acclimatization \\ Radzików, 05-870 Blonie, Poland
}

(Received 29 June 2001; accepted 7 August 2001)

\section{ABSTRACT}

One hundred forty four broiler cockerels, four-day old, were allocated to the four dictary treatments in a $4 \times 2$ factorial design experiment. The control diet was based on wheat while the four experimental diets contained four different varieties of rye and were supplemented either with xylanase or arabinofuranosidase or both enzymes together. Additionally, the dose effect of above enzymes on viscosity of water extract of rye was also examined. The obtained results showed, that xylanase plays an essential role in degradation of arabinoxylan polymers. All productive parameters were greatly enhanced when the diets were supplemented with xylanase preparation. The highest improvement was observed in body weight gain $(37 \pm 4.5 \%)$ and the lowest in digestibility of dry matter $(5 \pm 2.5 \%)$. In contrast to xylanase the effect of addition of arabinofuranosidase on improvement of growth performance of broiler chickens was distinctly less marked (from 9 to $0.4 \%$ ). The effect of supplementation of rye diets with both enzymes was additive. The same tendency was observed in in vitro study. The greatest reduction in viscosity of water extract was obtained after incubation of water suspension of ground rye with xylanase and this effect was dose dependent. The viscosity of rye extract has been reduced by $67 \%$ in case of xylanase, by $45 \%$ in case of arabinofuranosidase and by $71 \%$ in case of both enzymes added at the same concentration as in in vivo study. It seems, that fragmentation of the xylan backbone is decisive for utilization of rye by chickens.

KYE WORDS: rye, xylanase, arabinofuranosidase, broiler chickens, nutritive valuc, viscosity

\footnotetext{
* Supported in part by the State Committee for Scientific Research, Grant No. PB 610/PO6/95/08
} 


\section{INTRODUCTION}

It has been generally accepted, that the soluble and highly viscous arabinoxylans are the major detrimental component in diet based on rye for broiler chickens. Much of the harmful effect of rye can be eliminated by either reducing the amount of arabinoxylans or by supplementation of the diet with enzymes capable to hydrolyse these polysaccharides (Boros et al., 1985, Petersson and Åman, 1988, 1989; GrootWassink et al., 1989: Pettersson et al., 1990; Bedford et al., 1991; Fricsen et al., 1991; Marquardt et al., 1994; Smulikowska and Mieczkowska, 1996). However, none of these strategies completely eliminate the antinutritive properties of rye (Boros et al., 1995, 1997).

In an attempt to look closer into the degradation process of rye arabinoxylans, the effect of xylanase and arabinofuranosidase added separately and together was cxamined in vivo and in vitro.

\section{MATERIAL AND METHODS}

Cereals

Three varieties of rye: Amilo, Warko and Marder and the strain of hybrid RAH 797 were used in the current study. Wheat, variety Almari, served as a control. All cereals used represented winter forms and were grown under similar soil-climate conditions in Radzików (Warsaw region).

\section{Diets and growth trial}

The growth trial was performed on 144 one week-old cockerels (Hybro G), at the average initial weight of $109.8 \pm 18.4 \mathrm{~g}$, kept in individual cages. The design of the experiment was a $4 \times 2$ factorial ( 4 rye varieties $\times 2$ enzymes). Each diet had eight replicates with one bird per replicate. The diets were formulated to meet the requirements for broiler chickens as was described Boros and Bedford (1999). The rye diets were supplemented with $1 \mathrm{~g} / \mathrm{kg}$ of commercial enzyme preparation from Trichoderma longibrachiatum (containing xylanase activities 2700 units per g measured at $40^{\circ} \mathrm{C}$ and $\mathrm{pH} 5.3$ ) or/and with $1 \mathrm{ml} / \mathrm{kg}$ of arabinofuranosidase in a liquid form, containing $1 \mathrm{U} / \mathrm{g}$ measured with the use of p-nitrophenyl-a-L-arabinofuranosidase as a substrate, incubated at $40^{\circ} \mathrm{C}$ and $\mathrm{pH} 5.0$ for $30 \mathrm{~min}$ ).

The experimental diets were offered in a mash form and fed to the birds for a period of 14 days. Birds had free access to feed and water during the experiment and were exposed to constant light. Each time before weighing chickens were starved for $4 \mathrm{~h}$. Excreta samples were collected quantitatively over $72 \mathrm{~h}$ period 
during 12-14 days of the experiment for determination of apparent dry matter digestibility (DMD). The following growth performance criteria were evaluated: feed intake, body weight gain (BWG) and feed to gain ratio (FCR).

\section{In vitro trial}

A $1 \mathrm{~g}$ of ground rye, variety Amilo, was mixed with $5 \mathrm{ml}$ of distilled water in Erlenmeyer flask. In enzyme treatment xylanase and arabinofuranosidase were added separately or together at the increasing amounts (Figure 2). Such prepared suspension was incubated $1 \mathrm{~h}$ at $40^{\circ} \mathrm{C}$ in shaking water bath and then was transferred to centrifuge tube and centrifuged at $10000 \mathrm{rpm}$ for $10 \mathrm{~min}$. The resulting supernatant was taken for viscosity measurement as described below.

\section{Analyses}

Prior to analysis and in vitro trial all samples were ground to a particle size less than $0.5 \mathrm{~mm}$.

Dry matter content was determined by drying the samples at $105^{\circ} \mathrm{C}$ for $20 \mathrm{~h}$. Viscosity of water extract was determined using a Brookficld cone-plate viscometer (Model LVDV-II+, Brookfield Engineering Laboratories Inc. Stoughton, MA) as described by Boros et al. (1997).

Soluble dietary fibre (SDF) was determined by gravimetric method (AOAC, 1990), whereas soluble arabinoxylans (SAX) by GC method as aldononitrile acetates according to procedure of McGinnis (1982).

The data were subjected to two-way analysis of variance to determine the effect of enzyme supplementation. Comparisons between the wheat and the rye containing diets were accomplished using Duncan's multiple range test. The minimum level of statistical significance was $\mathrm{P} \leq 0.05$.

\section{RESULTS AND DISCUSSION}

The content of SDF, SAX and WEV of rye and the results of fecding study are summarized in Table 1 . There were significant differences $(\mathrm{P} \leq 0.0001)$ in feed intake and its utilization by chickens fed diets based on four different varieties of rye, although the birds had similar body weight gain. The best feed utilization and digestibility of dry matter were obtained in chickens fed on diet containing rye hybrid with the lowest WEV and ratio of WEV to SAX. These results confirmed earlier findings by Boros and Bedford (1999) indicating the possible decisive role of the arabinoxylan structure on viscosity of water extract, which in turn affects the nutritive value of rye. The lack of interactions between rye varieties and en- 
TABLE 1 The effect of supplementation of diets based on four varicties of rye with arabinoxylan degrading enzymes, xylanase (X) and arabinofuranosidase (A), on growth parameters of broiler chickens

\begin{tabular}{|c|c|c|c|c|c|c|c|}
\hline Grain & $\begin{array}{l}\text { WEV } \\
\text { mPa.s }\end{array}$ & $\begin{array}{c}\text { SDF mg/g } \\
(\mathrm{SAX} ; \\
\text { WEV/SAX) }\end{array}$ & $\begin{array}{l}\text { Enzyme } \\
\text { addition }\end{array}$ & $\begin{array}{l}\text { Diet intake } \\
\mathrm{g} / 14 \text { days }\end{array}$ & $\begin{array}{l}\text { Weight } \\
\text { gain } \\
\text { g/14 days }\end{array}$ & $\begin{array}{c}\text { Feed } \\
\text { conversion }\end{array}$ & $\begin{array}{c}\text { Dry matter } \\
\text { digestibility } \\
\%\end{array}$ \\
\hline \multirow[t]{4}{*}{ Amilo } & $6.67 \pm 0.05$ & $5.24 \pm 0.26$ & - & 420 & 238 & 1.811 & 66.9 \\
\hline & & $(2.00 ; 0.33)$ & $\mathrm{X}$ & $492^{*}$ & $333^{* *}$ & $1.478^{* *}$ & $71.3^{*}$ \\
\hline & & & A & 421 & 256 & $1.670^{*}$ & 68.5 \\
\hline & & & $\mathrm{XA}$ & 468 & $324^{* *}$ & $1.446^{* *}$ & $73.5 * *$ \\
\hline \multirow[t]{4}{*}{ RAH 797} & $5.49 \neq 0.06$ & $5.96 \pm 0.31$ & - & 402 & 240 & 1.689 & 71.0 \\
\hline & & $(2.00 ; 0.27)$ & $\mathrm{X}$ & $498^{*}$ & $341^{* *}$ & $1.462^{*}$ & 72.2 \\
\hline & & & A & 451 & $295^{*}$ & 1.548 & 70.7 \\
\hline & & & $x \wedge$ & $495^{*}$ & $344 * *$ & $1.446^{*}$ & $75.9^{*}$ \\
\hline \multirow[t]{4}{*}{ Marder } & $5.52 \pm 0.03$ & $4.88 \pm 0.24$ & - & 455 & 241 & 1.905 & 66.2 \\
\hline & & $(1.61 ; 0.34)$ & $x$ & $533^{*}$ & $329^{* *}$ & $1.629^{* *}$ & 68.2 \\
\hline & & & A & 487 & 256 & 1.941 & 67.1 \\
\hline & & & $\mathrm{XA}$ & $556^{*}$ & $357 * *$ & $1.555^{* *}$ & $72.0^{*}$ \\
\hline \multirow[t]{4}{*}{ Warko } & $6.30 \pm 0.08$ & $4.84 \pm 0.07$ & - & 487 & 265 & 1.836 & 65.4 \\
\hline & & $(1.89 ; 0.33)$ & $\mathrm{x}$ & $583^{*}$ & $349^{* *}$ & 1.688 & $69.8^{*}$ \\
\hline & & & $\wedge$ & 535 & 269 & $2.013^{*}$ & 64.7 \\
\hline & & & $\mathrm{XA}$ & $591^{*}$ & $377^{* *}$ & $1.584^{*}$ & $69.8^{*}$ \\
\hline \multicolumn{3}{|c|}{ Pooled SEM } & & 24.2 & 17.2 & 0.060 & 1.25 \\
\hline \multicolumn{3}{|l|}{ Rye } & - & $440 \pm 38$ & $246 \pm 13$ & $1.81 \pm 0.1$ & $67.4 \pm 2.5$ \\
\hline \multicolumn{3}{|l|}{ Rye } & $x$ & $526142 * *$ & $338 \pm 9 * *$ & $1.56 \pm 0.1^{* *}$ & $70.4 \pm 1.8^{* *}$ \\
\hline \multicolumn{3}{|l|}{ Rye } & A & $474 \pm 49^{*}$ & $269 \pm 18$ & $1.79 \pm 0.2$ & $67.7 \pm 2.5$ \\
\hline \multicolumn{3}{|l|}{ Rye } & $\mathrm{XA}$ & $528 \pm 56^{* *}$ & $350 \pm 22^{* *}$ & $1.51 \pm 0.1^{* *}$ & $72.8 \pm 2.6 * *$ \\
\hline \multicolumn{8}{|c|}{ (b) Probability } \\
\hline \multicolumn{3}{|c|}{ Source of variation } & & $\mathbf{P}$ & $\mathbf{P}$ & $\mathbf{P}$ & $\mathbf{P}$ \\
\hline \multicolumn{3}{|l|}{ Rye } & & $0.000 \mathrm{I}$ & $0.139 !$ & $0.000 !$ & 0.0001 \\
\hline \multicolumn{3}{|l|}{ Enzyme } & & 0.0001 & 0.0001 & 0.0001 & 0.0001 \\
\hline \multicolumn{3}{|c|}{ Rye $\mathrm{x}$ enzyme } & & 0.9746 & 0.7961 & 0.1271 & 0.8153 \\
\hline
\end{tabular}

*, ** differences significant at $\mathrm{P} \leq 0.05$ and $\mathrm{P} \leq 0.01$, respectively as compared to unsuplemented diets

zymes demonstrated that enzymes used had various effect on growth performance of broiler chickens. All productive parameters were greatly enhanced when the rye diets were supplemented with xylanase preparation. The greatest improvement was observed in body weight gain $(37 \pm 4.5 \%)$ and the lowest in digestibility of dry matter $(5 \pm 2.5 \%)$. In contrast to xylanase the effect of arabinofuranosidase addition was less marked (from 9 to $-10 \%$ ) and not uniform. In this case, significant but contrasting differences were only observed in FCR, where for of two diets this 
productive parameter was improved $(\mathrm{P} \leq 0.05)$ and for one diet worsen $(\mathrm{P} \leq 0.05)$ as compared to chickens the values of FCR obtained on the same diets without enzyme supplementation. Chickens fed diets containing rye showed a significant reduction of feed intake, body weight gain, feed conversion ratio and dry matter digestibility by $16,30,21$ and $13 \%$, respectively, as compared to chickens fed control diet based on wheat (Figure 1). The improved performance parameters of chickens fed rye diets supplemented with both enzymes did not exceed the performance parameters obtained in chickens fed wheat diet and the results were similar to the data obtained previously with rye hybrids where combination of both enzymes was applied (Boros and Bedford, 1999).

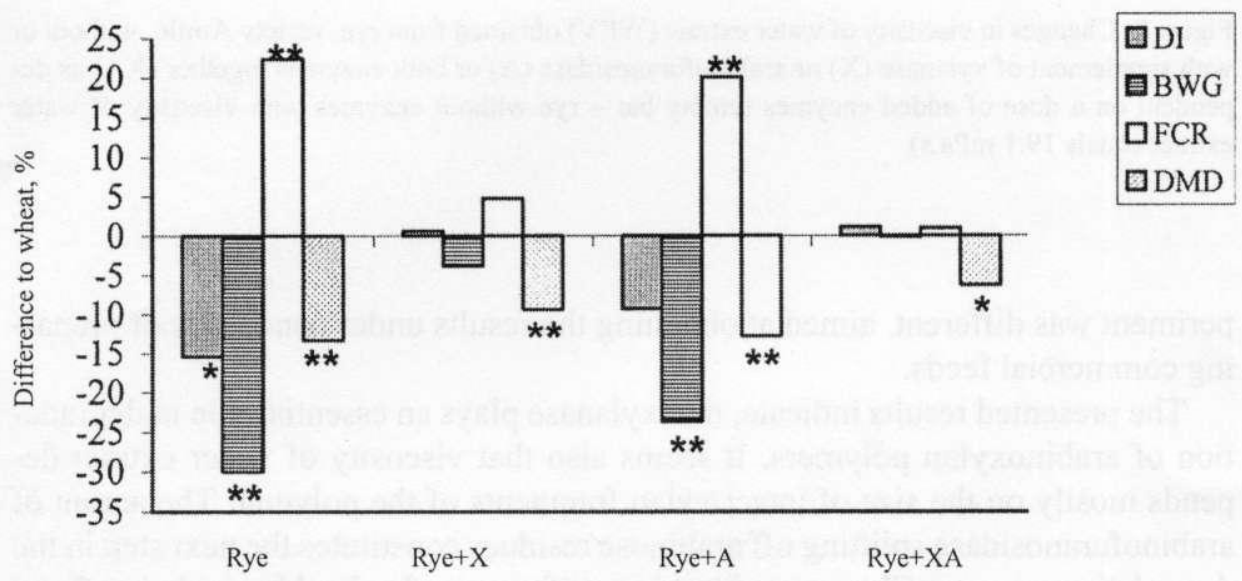

Figure 1. Differences in diet intake (DI), body weight gain (BWG), feed conversion ratio (FCR) and dry matter digestibility (DMD) of broiler chickens fed diets based on rye and supplemented with xylanase (X), arabinofuranosidase (A) or both enzymes together (XA) (average values from four diets containing different varieties of rye) in comparison with the same productive parameters obtained in broiler chickens fed control wheat diet $(*$, ** differences significant at $\mathrm{P} \leq 0.05$ and $\mathrm{P} \leq 0.01$, respectively)

The dose effect of above enzymes added to ground rye suspension on viscosity of water extract is illustrated in Figure 2. With an increasing dose of the enzymes the viscosity of rye extract has been reduced by $67 \%$ in case of xylanase, by $45 \%$ in case of arabinofuranosidase and by $71 \%$ in case of both enzymes added at the same concentration as in study in vivo. As was shown earlier (Boros et al., 1993) the combined enzymes added to the aqueous grain extract resulted in a rapid, almost total reduction of viscosity. However, the procedure used in the current ex- 


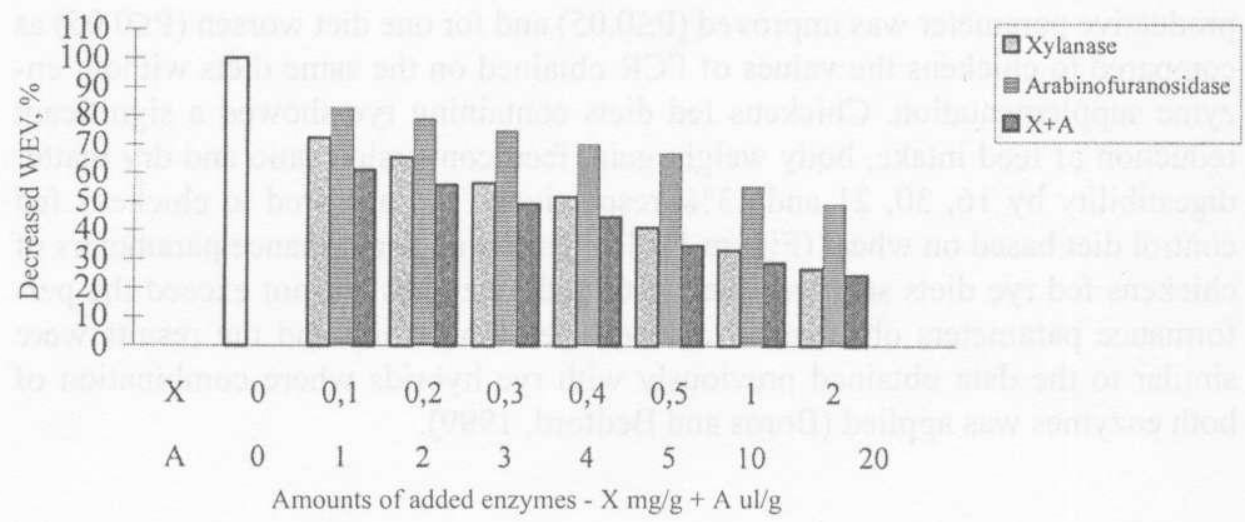

Figure 2. Changes in viscosity of water extract (WEV) obtained from rye, variety Amilo, without or with supplement of xylanase (X) or arabinofuranosidase (A) or both enzymes together (XA) as dependent on a dose of added enzymes (empty bar - rye without enzymes with viscosity of water extract equals $19.1 \mathrm{mPa} . \mathrm{s}$ )

periment was different, aimed at obtaining the results under conditions of preparing commercial feeds.

The presented results indicate, that xylanase plays an essential role in degradation of arabinoxylan polymers. It seems also that viscosity of water extract depends mostly on the size of intact xylan fragments of the polymer. The action of arabinofuranosidase splitting off arabinose residues constitutes the next step in the degradation process. Cleavage of arabinoses from a xylan backbone chain affects less both viscosity and nutrition parameters than the treatment with xylanase. The effect of both enzymes is additive.

It is known that arabinoxylans represent very heterogeneous polymers of different size, the extent of arabinoxylation and different sequence of arabinose substituents (Bengtsson and Åman, 1990; Bengtsson et al., 1992; Vinkx et al., 1993). However, it seems, that fragmentation of the xylan backbone is decisive for utilization of rye by chickens. One can not exclude the important co-effect of other enzymes such as cellulases, proteases and lipases probably acting on the grain cell walls. Therefore, it seems, that an enzyme supplement must contain a proper spectrum of enzymes to neutralize antinutrient components in rye diet.

\section{ACKNOWLEDGMENTS}

Authors are very grateful to Finnfeeds International Ltd. for the enzymes. 


\section{REFERENCES}

AOAC, 1990. Association of Official Analytical Chemists, Official Methods of Analysis. 15th Edition. Arlington, Virginia, USA

Bedford M.R., Classen H.L, Campbell G.L., 1991. The effect of pelleting, salt, and pentosanase on the viscosity of intestinal contents and the performance of broilers fed rye. Poultry Sci. 70 , 1571-1577

Bengtsson S., Aman P., 1990. Isolation and chemical characterization of water-soluble arabinoxylan in rye grain. Carbohyd. Polyn. 12, 267-277

Bengtsson S., Aman P., Andersson R.E., 1992. Structural studies on water-soluble arabinoxylans in rye grain using enzymatic hydrolysis. Carbohyd. Polym. 17, 277-284

Boros D., Bedford M., 1999. Influence of water extract viscosity and exogenous enzymes on nutritive value of rye hybrids in broiler diets. J. Anim. Feed Sci. 8, 579-588

Boros D., Madej L., Jagodziński J., 1997. Perspectives of selection for better nutritive quality of rye. I. Viscosity of grain extract as an index of nutritive value of rye for broiler chicks. Plant Breed. Seed Sci. 41, 81-89

Boros D., Marquardt R.R., Guenter W., 1995. Rye as an alternative grain in commercial broiler feeding. J. Appl. Poultry Res. 4, 34l-351

Boros D., Marquardt R.R., Slominski B.A., Guenter W., 1993. Extract viscosity as an indirect assay for water-soluble pentosan content in rye. Cereal Chem. 70, 575-580

Boros D., Rakowska M., Raczyńska-Bojanowska K., Kozaczyński K., 1985. The response of Japanese quails and chicks to the water-soluble antinutritive compounds from rye grain. Nutr. Rep. lnt. $32,827-836$

Duncan D.G., 1955. Multiple range and multiple F tests Biometrics 11, 1-42

Friesen O.D., Guenter W., Rotter B.A., Marquardt R.R., 1991. The effects of enzyme supplementation on the nutritive value of rye grain (Secale cereale) for the young broiler chick. Poultry Sci. $70,2501-2508$

GrootWassink J.W.D., Campbell G.L., Classen H.L., 1989. Fractionation of crude pentosanase (arabinoxylanase) for improvement of the nutritional value of rye diets for broiler chickens. J. Sci. Food Agr. 46, 289-300

Marquardt R.R., Boros D., Guenter W., Crow G., 1994. The nutritive value of barley, rye, wheat and com for young chicks as affected by use of a Trichoderma reesei enzyme preparation. Anim. Feed Sci. Tech. 45, 363-378

McGinnis G.D., 1982. Preparation of aldononitrile acetates using N-methylimidazole as catalyst and solvent. Carbohyd. Res. 108, 284-292

Pettersson D., Aman P., 1988. Effects of enzyme supplementation of diets based on wheat, rye or triticale on their productive value for broiler chickens. Anim. Feed Sci. Tech. 20, 313-324

Pettersson D., Åman P., 1989. Enzyme supplementation of a poultry diet containing ryc and wheat. Brit. J. Nutr. 62, 139-149

Pettersson D., Graham H., Aman P., 1990. Enzyme supplementation of broiler chicken diets based on cercals with endosperm cell walls rich in arabinoxylans or mixed-linked B-glucans. Anim. Prod. 5l, 20l-207

Pettersson D., Graham H., Åman P., 1991. The nutritive value for broiler chickens of pelleting and enzyme supplementation of a dict containing barley, wheat and rye. Anim. Feed Sci. Tech. 33, $1-14$

Smulikowska S., Mieczkowska A., 1996. Effect of rye level, fat source and enzyme supplementation on fat utilization, diet metabolizable energy, intestinal viscosity and performance of broiler chickens. J. Anim Feed Sci. 5, 379-393 
Vinkx C.J.A., Reynaert H.R., Grobet J., Delcour J.A., 1993. Physicochemical and functional properties of rye nonstarch polysaccharides. V. Variability in the structure of water-soluble arabinoxylans. Cereal Chem. 70, 311-317

\section{STRESZCZENIE}

\section{Wplyw uzupełniania diet żytnich enzymami hydrolizującymi arabinoksylany na wskaźniki pro- dukcyjne kurcząt brojlerów}

Doświadczenie wzrostowe w układzie czynnikowym $4 \times 2$, przeprowadzono na 144 czterodniowych kogutkach brojlerach, podzielonych na eztery grupy. Dietami doświadezalnymi były diety zawierające cztery różne odmiany żyta uzupełnione ksylanazą lub arabinoksylanazą, bądź dwoma tymi enzymami jednocześnie. Dietą kontrolną była dieta pszenna. Dodatkowo badano wpływ różnych koncentracji powyższych enzymów dodanych do wodnej zawiesiny ziarna żyta na spadek lepkości otrzymanego ekstraktu. Otrzymane wyniki pokazały, że ksylanaza odgrywa główną rolę w procesie degradacji polimerów arabinoksylanów. Wszystkie wskaźniki produkcyjne były istotnie poprawione po uzupełnieniu diet preparatem ksylanazy. Największą poprawę uzyskano w przyroście masy ciała $(37 \pm 4,5 \%)$, najmniejszą zaś w strawności suchej masy $(5 \pm 2.5 \%)$. W przeciwieństwie do ksylanazy, dodatek arabinofuranozydazy tylko nieznacznie wpływał na poprawę wartości tych wskaźników (ođ 9 do 0,4\%). Dodatek obydwóch tych enzymów jednocześnie miał efekt sumujący. Podobną tendencję obserwowano w badaniach in vitro. Największy spadek lepkości stwierdzono w ekstrakcie wodnym uzyskanym z zawiesiny ziarna żyta inkubowanej z dodatkiem ksylanazy i spadek ten zwiększał się w miarę zwiększania ilości dodanego enzymu. Lepkość wodnego ekstraktu była obniżona o $67 \%$ w przypadku dodania ksylanazy, o $45 \% \mathrm{w}$ przypadku dodania arabinofuranozydazy i o $71 \% \mathrm{w}$ przypadku dodania obydwóch tych enzymów łącznie w ilości korespondującej z ilością użytą jak $w$ badaniach in vivo. Można sądzić zatem, że fragmentacja łańcucha ksylozowego ma decydujące znaczenie w wykorzystaniu żyta przez kurczęta. 